\title{
Pseudomembranous colitis
}

\section{Mona Z Zaghloul}

Department of Clinical Pathology, Microbiology Unit, Ain Shams University Hospitals, Egypt

*Corresponding author: Mona Z Zaghloul, Department of Clinical Pathology, Microbiology Unit, Ain Shams University Hospitals, Egypt, Tel: 02-2402349; E-mail: monazaki_810@hotmail.com

Received date: June 08, 2014, Accepted date: June 11, 2014, Published date: June 14, 2014

Copyright: (c) 2014 Zaghloul MZ. This is an open-access article distributed under the terms of the Creative Commons Attribution License, which permits unrestricted use, distribution, and reproduction in any medium, provided the original author and source are credited.

\section{Editorial}

In $1978, C$. difficile was identified as the causative agent of pseudomembranous colitis [1]. There has been a worldwide increase in the incidence and severity of $C$. difficile-associated diarrhea (CDAD) due to increased use of broad-spectrum antimicrobial, crowded hospital wards [2,3] and/or poor infection control [4,5]. Pseudomembranous colitis associated with antibiotic use may alter the balance of normal flora of the intestine and allow overgrowth of certain organisms such as $C$. difficile [6] which is a gram-positive, sporeforming, anaerobic bacillus its main virulence determinants are toxin A (enterotoxin) and toxin B (cytotoxin) [7]. The increased amounts of these toxins possibly related to a truncating mutation in the $t c d C$ gene, which codes for a putative repressor of toxin $\mathrm{A} / \mathrm{B}$ production $[8,9]$. Toxin A interferes with colonic mucosal cell adherence to colonic basement membrane and damages villous tips while toxin $B$ enters the cell by endocytosis and induces apoptosis [10]. Not only clindamycin, lincomycin, ampicillin and cephalosporin have been implicated in most cases of pseudomembranous colitis but also antifungal, antiviral, and metronidazole could incite the disease. The illness is characterized by offensive-smelling diarrhea, fever, leukocytosis and abdominal pain. Life-threatening complications can develop in severe cases such as toxic megacolon [11]. Diabetics, elderly, intensive care unit patients and recent major surgery is the main risk factors [12] also there are some evidence that proton pump inhibitors are a risk factor for pseudomembranous colitis [13]. Non antimicrobial $C$. difficile pseudomembranous colitis was reported in many conditions as bowel ischemia, recent bowel surgery, uremia, chemotherapy and Hirsch sprung disease.

The toxins produced by $C$. difficile could be detected by various methods including enzyme immunoassay (EIA), cell cytotoxicity assay or real-time polymerase chain reaction (PCR) for toxin B gene $(t c d B)$ determination [14]. There is some controversy regarding the sensitivity and specificity of the various toxin assays, so repeat toxin testing at least once after a negative result is necessary [15] or use a two-step method of detection, incorporating bacterial antigen or culture [16,17]. Pseudomembranous colitis could be treated by discontinuation of antibiotics and oral vancomycin, intravenous or oral metronidazole is recommended as first-line treatments for mild to moderate disease without complications. Complicated cases as toxic megacolon, perforation and acute abdomen may require surgical intervention by subtotal colectomy with ileostomy [18]. A randomized controlled trial using a probiotic drink containing Lactobacillus casei, L. bulgaricus, and Streptococcus thermophilus was reported to have some efficacy. However, this study was, sponsored by the company that produces the drink [13].

\section{References}

1. Rifkin GD, Fekety FR, Silva J, Sack RB (1977) Antibiotic-induced colitis implication of a toxin neutralised by clostridium sordellii antitoxin. Lancet 2: 1103-1106.

2. Muto CA, Pokrywka M, Shutt K, Mendelsohn AB, Nouri K, et al. (2005) A large outbreak of Clostridium difficile-associated disease with an unexpected proportion of deaths and colectomies at a teaching hospital following increased fluoroquinolone use. Infect Control Hosp Epidemiol 26: $273-280$

3. Davey P, Brown E, Fenelon L, Finch R, Gould I, et al. (2008) Interventions to improve antibiotic prescribing practices for hospital inpatients. Cochrane Database Syst Rev 77: 618-619.

4. Ward CO (2003) Diagnosis, treatment, and prevention of Clostridium difficile colitis. Consult Pharm 18: 1050-1054.

5. Weiss K (2006) Poor infection control, not fluoroquinolones, likely to be primary cause of Clostridium difficile-associated diarrhea outbreaks in Quebec. Clin Infect Dis 42: 725-727.

6. McFarland LV (2008) Antibiotic-associated diarrhea: epidemiology, trends and treatment. Future Microbiol 3: 563-578.

7. Kilic A (2013) Clostridium difficile infection: epidemiology, risk factors, pathogenesis, clinical features, diagnosis and therapy. Mikrobiyol Bul 47: 556-566.

8. Muto CA, Pokrywka M, Shutt K, Mendelsohn AB, Nouri K, et al. (2005) A large outbreak of Clostridium difficile-associated disease with an unexpected proportion of deaths and colectomies at a teaching hospital following increased fluoroquinolone use. Infect Control Hosp Epidemiol 26: 273-280.

9. Dupuy B, Govind R, Antunes A, Matamouros S (2008) Clostridium difficile toxin synthesis is negatively regulated by TcdC. J Med Microbiol 57: 685-689.

10. Tonna I, Welsby PD (2005) Pathogenesis and treatment of Clostridium difficile infection. Postgrad Med J 81: 367-369.

11. Earhart MM (2008) The identification and treatment of toxic megacolon secondary to pseudomembranous colitis. Dimens Crit Care Nurs 27: 249-254.

12. Greenstein AJ, Byrn JC, Zhang LP, Swedish KA, Jahn AE, et al. (2008) Risk factors for the development of fulminant Clostridium difficile colitis. Surgery 143: 623-629.

13. Hickson M, D'Souza AL, Muthu N, Rogers TR, Want S, et al. (2007) Use of probiotic Lactobacillus preparation to prevent diarrhoea associated with antibiotics: randomised double blind placebo controlled trial. BMJ 335: 80.

14. Leis JA, Gold WL, Ng J, Hirji Z, Pillai DR, et al. (2013) Indeterminate tcdB using a Clostridium difficile PCR assay: a retrospective cohort study. BMC Infect Dis 13: 324 .

15. Bartlett JG (2002) Clinical practice. Antibiotic-associated diarrhea. N Engl J Med 346: 334-349.

16. Reller ME, Lema CA, Perl TM, Cai M, Ross TL, et al. (2007) Yield of stool culture with isolate toxin testing versus a two-step algorithm including stool toxin testing for detection of toxigenic Clostridium difficile. J Clin Microbiol 45: 3601-3605.

17. Ticehurst JR, Aird DZ, Dam LM, Borek AP, Hargrove JT, et al. (2006) Effective detection of toxigenic Clostridium difficile by a two-step 
Citation: Zaghloul MZ (2014) Pseudomembranous colitis. Trop Med Surg 2: e120. doi:10.4172/2329-9088.1000e120

Page 2 of 2

algorithm including tests for antigen and cytotoxin. J Clin Microbiol 44 1145-1149.
18. Seltman AK (2012) Surgical Management of Clostridium difficile Colitis. Clin Colon Rectal Surg 25: 204-209. 